\title{
Communicating Managed Retreat in California
}

\author{
Wendy Karen Bragg ${ }^{1}$, Sara Tasse Gonzalez ${ }^{1}$ (D) , Ando Rabearisoa ${ }^{1}$ and Amanda Daria Stoltz ${ }^{2, *(\mathbb{D})}$ \\ 1 Department of Ecology and Evolutionary Biology, University of California, Santa Cruz, CA 95060, USA; \\ wbragg@ucsc.edu (W.K.B.); satgonza@ucsc.edu (S.T.G.); arabeari@ucsc.edu (A.R.) \\ 2 Department of Environmental Studies, University of California, Santa Cruz, CA 95060, USA \\ * Correspondence: astoltz@ucsc.edu; Tel.: +1-301-356-3496
}

check for

updates

Citation: Bragg, W.K.; Gonzalez, S.T.; Rabearisoa, A.; Stoltz, A.D.

Communicating Managed Retreat in California. Water 2021, 13, 781.

https://doi.org/10.3390/w13060781

Academic Editor: Borja G. Reguero

Received: 10 February 2021

Accepted: 11 March 2021

Published: 13 March 2021

Publisher's Note: MDPI stays neutral with regard to jurisdictional claims in published maps and institutional affiliations.

Copyright: (c) 2021 by the authors. Licensee MDPI, Basel, Switzerland. This article is an open access article distributed under the terms and conditions of the Creative Commons Attribution (CC BY) license (https:// creativecommons.org/licenses/by/ $4.0 /)$.

\begin{abstract}
California cities face growing threats from sea-level rise as increased frequency and severity of flooding and storms cause devastating erosion, infrastructure damage, and loss of property. Management plans are often designed to prevent or slow flooding with short-term, defensive strategies such as shoreline hardening, beach nourishment, and living shorelines. By contrast, managed retreat focuses on avoiding hazards and adapting to changing shorelines by relocating out of harm's way. However, the term "managed retreat" can be controversial and has engendered heated debates, defensive protests, and steady resistance in some communities. Such responses have stymied inclusion of managed retreat in adaptation plans, and in some cases has resulted in complete abandonment of the policy review process. We examined the Local Coastal Program review process in seven California communities at imminent risk of sea-level rise and categorized each case as receptive or resistant to managed retreat. Three prominent themes distinguished the two groups: (1) inclusivity, timing, and consistency of communication, (2) property ownership, and (3) stakeholder reluctance to change. We examined use of terminology and communication strategies and provided recommendations to communicate "managed retreat" more effectively.
\end{abstract}

Keywords: adaptation; California; managed retreat; sea-level rise; climate change communication

\section{Introduction}

Sea-level rise (SLR) and other effects of climate change in coastal areas pose a threat to ecosystems, societies, and property, and timely management is critical for protecting coastal communities. In California, rising sea levels will prompt more severe flooding from El Niño events, higher king tides, storm surges, and wave-driven erosion [1]. A recent study by researchers from the U.S. Geological Survey estimated that by 2100 over 600,000 California residents and $\$ 150$ billion of property could be impacted by coastal flooding [2]. In response to these threats, government agencies have historically tended to create top-down climate policy measures that limit citizen agency and can create conflict and resistance from communities when implemented [3].

Coastal adaptation strategies often begin by forming a vulnerability assessment to understand the possible future effects of SLR, followed by a risk assessment to identify and prioritize particular hazard areas and infrastructure [4]. Based on these assessments, an adaptation plan puts forth a plan of action, which generally includes one or more of the following strategies: protect, accommodate, or retreat [5]. Protection strategies may use engineered structures such as riprap or seawalls ("hard" defenses), as well as living shorelines, dune or wetland restoration, and beach nourishment ("soft" defenses) to defend property at the shoreline [6]. Accommodation strategies modify existing structures to be elevated above the projected floodline, or design new structures that can be easily relocated when the threat from SLR increases [5]. Retreat can be achieved through implementing zoning ordinances where new developments are prohibited in certain hazard areas, buyout programs in which the government acquires ownership of properties in flood-prone areas, and/or the physical removal or relocation of property [7]. Adaptation plans frequently 
include a hybrid of protection, accommodation, and retreat strategies, with trigger points or thresholds to indicate when a new action will be implemented.

Of the most common adaptation strategies, managed retreat is usually the surest way to protect people and property from SLR [8]. In managed retreat, human societies adapt to changing shorelines due to SLR by moving out of harm's way, rather than attempting to prevent the shoreline from changing with infrastructure $[7,8]$. This proactive management strategy usually involves replacing hard shoreline defenses with intertidal habitat, dunes, or other natural buffers, and relocating people, homes, and infrastructure to safer areas [9-11]. Over the long term, managed retreat is likely to be less costly than protection strategies that involve maintenance of hard infrastructure or eventual dismantling of eroded property $[10,12]$. Barriers may provide a false sense of security and may lead to increased property development at the shore, ultimately putting more people at risk [9]. To complement managed retreat, setbacks can be used to require that new developments be at a minimum distance from the shoreline to keep out of the hazardous area [7]. For example, to adapt to the constantly changing shoreline in Maui, Hawaii, the local government has implemented site-specific, dynamic, erosion-rate based setback distances using projected shoreline retreat inland over a building's lifespan [13]. Similarly, in North Carolina, setbacks are calculated based on 30-90 times the long-term average annual erosion rate, depending on the size of the structure [14]. However, these measures are considered temporary solutions until managed retreat at the broader scale can be implemented [7]. Managed retreat is a strategy for sustainable development that should be considered in areas throughout the world with low elevations or coastal regions that experience repeated traumatic climatic events, such as sea-level rise and river flooding [15]. Urban expansion in these vulnerable areas has escalated the urgent need for action to mitigate risks such as flash floods [16,17].

In California, coastal management is planned and regulated through a partnership of federal, state, and local authorities that comprise the California Coastal Management Program (CCMP) [18]. Where coastal development is concerned, the California Coastal Commission (CCC), an agency of CCMP, manages and approves permits, appeals, and Local Coastal Programs (LCPs; essential planning tools that guide coastal development). The CCC evaluates LCPs based on their adherence to policies under the California Coastal Act of 1976, which addresses issues such as shoreline public access, habitat protection, and development design. LCPs are reviewed by the CCC every five years to ensure that coastal resources remain protected given new information and changing environmental and developmental impacts [18]. LCPs must be revised and revisited often to incorporate adaptation plans with new strategies [4].

The California Resources Agency's 2001 policy on coastal erosion response states that evaluating the feasibility of relocating existing properties (i.e., managed retreat) should be a "first priority" over other strategies such as beach nourishment [19]. In many coastal areas, managed retreat will be the only or best option because of long-term economic and geological considerations. Unfortunately, managed retreat is often met with pushback from property owners who view seawalls and other hard infrastructure as more favorable [20] as well as from residents with strong emotional ties to their homes and lifestyles [21].

In this report, we examine attempted and successful managed retreat efforts across the California coast with a focus on how adaptation plans were communicated to residents. Climate-related problems are commonly met with cognitive and emotional responses, as the problems are distressing, misunderstood, difficult to treat, and diverse [22]. Common emotions include a feeling of helplessness, denial, criticism, shifting attention to other issues, apathy, fatalism, or other forms of "capitulating imagination" [23]. Cognitive barriers to active engagement on managed retreat could include misunderstanding or denial of the issue, the causes, and the impacts of the problem to human life; misunderstanding or disagreement with the policies and strategies proposed by policymakers; an unattractive future vision; and lack of resonance with the framing and language in which managed retreat is being discussed [24]. Here, in the context of California case studies, we discuss 
the implications of the wording and communication of "managed retreat" for community receptiveness to the adaptation plan and suggest recommendations for more effective communication of the concept of managed retreat in the future.

The objectives of this report were to identify (1) cases of community resistance to managed retreat in California, (2) cases of community receptiveness toward managed retreat in California, (3) how managed retreat was communicated in each case, and (4) recommendations for effectively communicating ideas in future managed retreat initiatives. Our study identifies a knowledge gap in understanding community receptiveness and resistance toward managed retreat and lays a foundation for future research on communicating and rebranding managed retreat for successful management outcomes.

\section{Materials and Methods}

The analysis is based on a review of case studies across California communities that have considered managed retreat as a coastal adaptation option.

- We conducted a literature review of managed retreat in California through Web of Science and Google Scholar, focusing on journal articles with both the keywords "managed retreat" and "California" dating from 1990-2020.

- We conducted online searches for "managed retreat in California" and "coastal adaptation in California" which led to many articles identifying cities facing substantial loss of land and property from SLR and erosion that have considered or have successfully incorporated managed retreat into their LCP.

- We coded each identified location for the following categories: (i) whether the term managed retreat was used, and (ii) the success or failure of managed retreat initiatives. A total of ten communities were identified through the review as potential cases.

- Seven cases were selected for analysis based on the following criteria: (1) public records demonstrating that community members were confronted with the term "managed retreat" either through workshops, meetings, or attempted adaptation plans, and (2) a clear determination of whether managed retreat is included in the LCP. These cases also represent varied contexts and span much of the coast of California (Figure 1), which make the commonalities between them substantial evidence for future adaptation strategies.

- We reviewed the climate adaptation planning documents for each of these cases.

- We identified factors that contributed to either community receptiveness or resistance toward managed retreat and grouped these cases as either receptive or resistant to managed retreat (Table 1).

Table 1. Description and categorization of selected case studies in California.

\begin{tabular}{ccc}
\hline Case Study & Description and Location & $\begin{array}{c}\text { Resistant or Receptive } \\
\text { To Managed Retreat }\end{array}$ \\
\hline King Salmon & $\begin{array}{c}\text { Coastal Community in } \\
\text { Humboldt County } \\
\text { Coastal Community in San } \\
\text { Diego County } \\
\text { Del Mar }\end{array}$ & Resistant \\
Pacifica & $\begin{array}{c}\text { Coastal Community in San } \\
\text { Mateo County }\end{array}$ & Resistant \\
Imperial Beach & $\begin{array}{c}\text { Coastal Community in San } \\
\text { Diego County } \\
\text { Surfers' Point }\end{array}$ & $\begin{array}{c}\text { Beach in Ventura County } \\
\text { Beach in San Francisco } \\
\text { County }\end{array}$ \\
South Ocean Beach & Coastal Community in \\
Monterey County & Receptive \\
Marina & Receptive \\
\hline
\end{tabular}




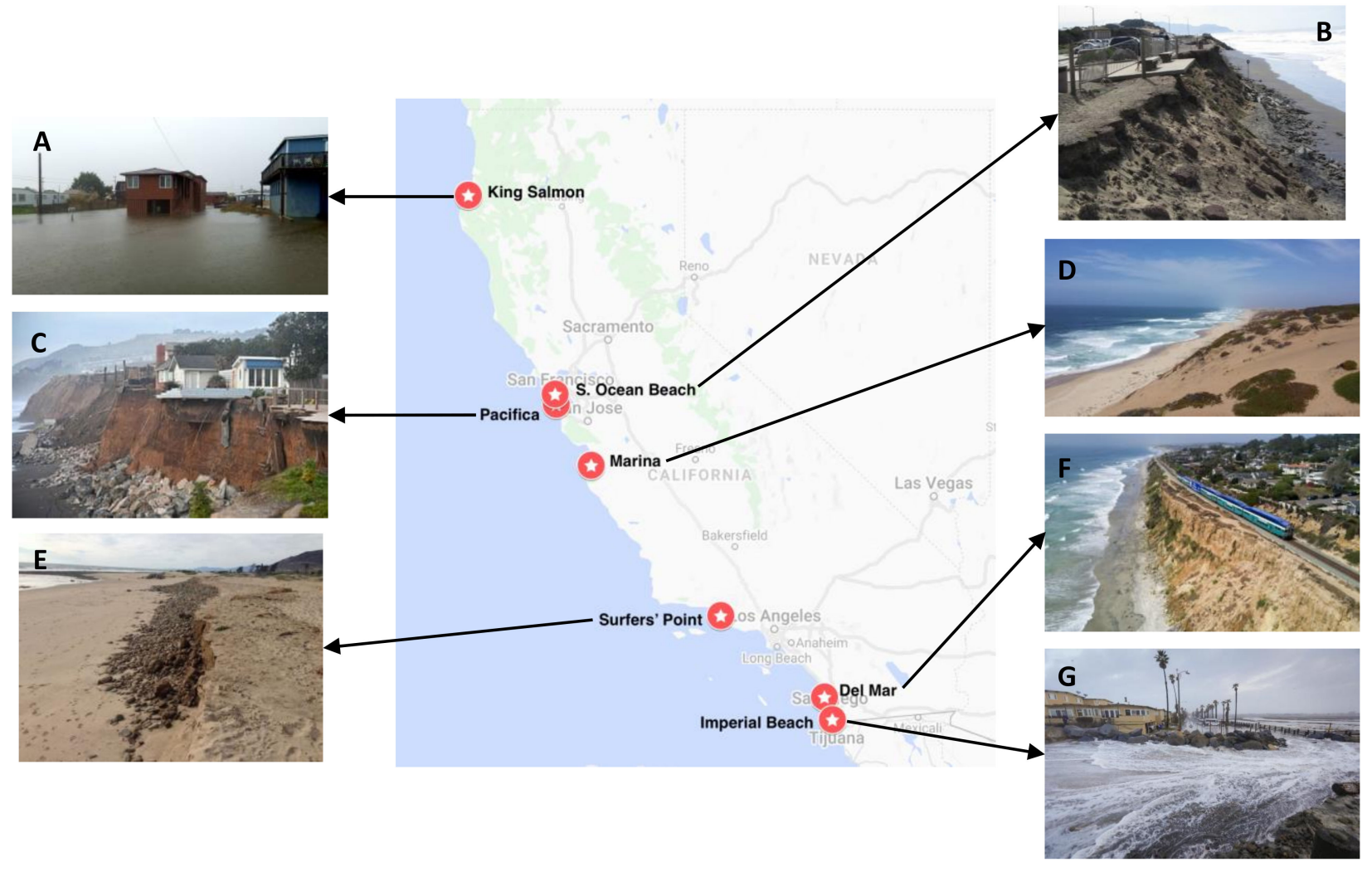

Figure 1. Locations and photographs of managed retreat case studies. (A) King Salmon (Photo: Kristina Kunkel) (B) South Ocean Beach (Photo: San Francisco Public Works 2014) (C) Pacifica (Photo: Josh Edelson/AFP via Getty Images) (D) Marina (Photo: CaliforniaBeaches.com) (E) Surfers' Point (Photo: Paul Jenkin) (F) Del Mar (Photo: John Gibbins. Copyright @ 2019 Los Angeles Times. Reprinted with permission) (G) Imperial Beach (Photo: Howard Lipin. Copyright @ 2019 Los Angeles Times. Reprinted with permission).

Receptiveness was measured by the inclusion of managed retreat in the LCP without disclaimers undermining the option to progress to managed retreat (whether managed retreat was ultimately implemented). Resistance was measured by strong opposition at community meetings and the refusal to include a consideration of managed retreat in the LCP or, if included in the LCP, strict qualifiers negating the option of managed retreat.

- We identified differences in wording, framing, and communication of managed retreat between the receptive and resistant cases, to examine common misunderstandings and other factors that can undermine effective communication and collaboration between key stakeholders.

As an additional source of information, we reached out to experienced professionals and stakeholders from each community to learn more and to identify the knowledge and communication needed to inform future strategy through semi-structured, in-depth interviews with key stakeholders including consultants and local government officials. We also interviewed science policy experts from the Union of Concerned Scientists who authored the Underwater report (2018) on SLR, chronic flooding, and the implications for coastal U.S. real estate. All interviewees gave their informed consent for inclusion before they participated in the study. The study protocol was approved by the Office of Research Compliance Administration, University of California, Santa Cruz (USCS IRB Protocol \#HS3764).

Based on our comparative analysis of these case studies we provided recommendations for policymakers and coastal managers for future managed retreat projects. 


\section{Results}

3.1. Cases of Community Resistance to "Managed Retreat"

3.1.1. King Salmon

Located on Humboldt Bay in northern California, King Salmon is among the most vulnerable towns to SLR on the entire California coast [25]. This unique bayside community has a system of tidal channels that allows its residents to have docks adjacent to their homes. Most of the community, including the only access road, could be significantly impacted by SLR-related flooding by 2050 [25]. Furthermore, 72\% of residents in King Salmon meet the federal definition of economically disadvantaged [26], making the population resourcepoor and less likely to be prepared for SLR-related hazards [27-29]. These factors make managed retreat a necessary course of action and one of the only adaptation strategies available for this community. However, King Salmon residents indicated that they are willing to tolerate the floodwaters; indeed, they have already invested in pallets, cement blocks, and sandbags to protect their property, possessions, and infrastructure rather than move to a new location $[30,31]$. This potential bias against managed retreat was observed during the public comment section of the Communities at Risk public meeting in 2018 [30,32]. Such community bias against managed retreat is well documented [33-36]; however, it is not unanimous. Recent research on community knowledge and perceptions of flooding and SLR in King Salmon revealed a direct correlation between age and preferred adaptation method, where respondents aged 65 and older generally expressed a preference for staying rather than retreating in hopes that they will not live to experience the full severity of increased coastal flooding [30]. Research also shows that the economic status and worldview of the residents are key factors in how this communication should be approached given that some residents are opposed to the term, "sea-level rise" despite acknowledging that flooding in the area has worsened overtime [31]. King Salmon's LCP does not include plans for managed retreat, but as conditions in the area continue to degrade, residents will eventually be forced to move to other communities and that consideration should be given to buying out residential properties to encourage early relocation [31].

\subsubsection{Del Mar}

Just north of San Diego, the city of Del Mar faces imminent threats from SLR, with current seawalls expected to be inadequate for protecting low-elevation homes in the event of severe storm flooding [37]. The city established its Sea-Level Rise StakeholderTechnical Advisory Committee in 2015 to create plans to protect local beaches from SLR by including input from many stakeholders and to use these inputs to advise the Del Mar City Council [38]. After years of discussions, outreach, and public meetings, the Del Mar City Council created their 2018 Del Mar Sea Level Rise Adaptation Plan-an amendment to their existing LCP-which focused on beach nourishment, river dredging, living levees, and maintaining infrastructure such as seawalls to prevent flooding. However, the California Coastal Commission (CCC) returned several modifications, asking the city to include strategies that would address future extreme impacts of SLR, which involved identifying impact thresholds ("triggers") that would signal the need for action [39,40]. The Del Mar City Council unanimously rejected these modifications, arguing that "planned retreat (managed retreat) is not necessary or feasible in Del Mar," [41] since the small size of the city and expensive coastal property values limit retreat options [37]. While the CCC's report did not explicitly indicate that Del Mar must implement managed retreat, many residents perceived the language of additional coastal monitoring and identifying triggers to be synonymous with managed retreat [42]. In January 2020, the City of Del Mar planned to withdraw its original management plan and resubmit a modified version to the CCC in order to have more time to re-work the plan in accordance with the CCC's recommendations [43]. However, at a later council meeting, several public comments emphasized concern over managed retreat and encouraged the council to "hold their position" on their original adaptation plan and "stand their ground" with the CCC [44]. 


\subsubsection{Pacifica}

A town of 38,000 located in San Mateo County, CA, Pacifica had made progressive advances toward coastal management in recent years. Pacifica had relied on hard defenses including armoring and channelization until 1990 when the town established the Pacifica State Beach Master Plan which included managed retreat and was heralded as a model of success in 2005 [45]. At that time, two homes were purchased and removed in order to allow for dune reconstruction and beach and estuary restoration [45]. This history stands in sharp contrast to Pacifica's complete rejection of proposed managed retreat in the 2018 Preliminary Draft Adaptation Plan [46]. According to a local government official, the town held at least 5 open meetings where community members were paired with consultants and conflict resolution specialists to discuss views about the proposed plan. Meeting minutes document the mixture of support and opposition voiced by the community [47]. Residents opposed to the inclusion of managed retreat eventually organized and demanded the removal of the term from the final draft [48]. Some quotes by residents include: "'Managed retreat' is a code word for give up-on our homes and the town itself," and "the words are like a scarlet letter" [49]. According to a local government official, tensions heightened to the point that residents voted the mayor out of office. This rejection of managed retreat came only two years after damages from the 2015-2016 El Niño which cost the town $\$ 16$ million [49]. While this dramatic event could have provided momentum for making strides in coastal planning by highlighting both the long- and short-term impacts of SLR and severe weather, it appears to have done just the opposite. Despite looming impacts, city officials yielded to community protests, pivoting from Pacifica's heralded managed retreat strategies in 1990 back to hard defenses in 2018. The current LCP draft now recommends extending and replacing existing seawalls and stresses in multiple places that "the City has rejected managed retreat as a sea level rise adaptation policy" [50]. As it stands, a SLR of one foot, which has been predicted for Pacifica between 2050-2100 [1], could overwhelm the current coastal protections in Pacifica inflicting future damages and financial hardships on the town.

\subsubsection{Imperial Beach}

In San Diego county, Imperial Beach, which is prone to annual flooding of city streets, commissioned a study to examine the impacts of SLR on the city [51]. The report cautioned that rising sea levels could leave $30 \%$ of the town and $40 \%$ of the roads vulnerable to more frequent flooding [51], so the city undertook efforts to discuss coastal planning. However, despite yearly flood threats and the projected increases in king tides and SLR, residents had strong negative reactions to "managed retreat" when it was proposed by officials [52]. According to the LA Times, there was a "frenzy over managed retreat [where] fear overwhelm[ed] reason. Conspiracy theories and misinformation abound[ed]" [49]. While the city and consultants came up with an innovative plan to recoup costs and maximize homeowners' time in their houses by buying back the homes deemed most at-risk and then renting them back to current homeowners until conditions necessitated removal, these plans were met with large and vocal protests during meetings. This public sentiment was cited by the city when it removed managed retreat options from their plans entirely $[53,54]$, stating that "while managed retreat was included as a potential strategy in the [original assessment], the City does not consider it a viable or necessary adaptation strategy in the foreseeable future and does not intend to pursue it." Indeed, the experience was so charged that the mayor regretted initiating such a polarizing discussion that sidetracked progress on the broader planning efforts [52]. Rather than developing a future-looking plan, the city settled on continuing beach nourishment [53], despite studies indicating that sand replenishment is a temporary fix that requires continuous repetition [55] and carries with it prohibitive costs. 


\subsection{Cases of Community Receptiveness to "Managed Retreat"}

\subsubsection{Surfers' Point}

The Ventura River mouth, famous for its natural surf break that is widely popular among southern California residents, has experienced a receding shoreline at an average rate of $1.5 \mathrm{ft}$ per year since the late 1990s [56]. The deteriorating infrastructure along the shoreline became a safety hazard, so in 1995, the City of Ventura began plans to restore the beach. By 2005, after years of negotiations, the resulting plan-the Surfers' Point Managed Retreat Project-was created through coordinated effort among city planners as well as state and local organizations and was largely promoted by the local community [57]. The project focused on relocating a degraded bike path and parking lot, establishing a 65 -foot retreat zone, and restoring a natural beach area. This plan was made in accordance with recommendations from the Surfrider Foundation's Ventura County Chapter, a local community group formed in the early 1990s out of protest against the proposed beach armoring that would have destroyed the surf break and degraded the beach [56]. Instead of using hard infrastructure like a concrete seawall, cobble and sand replaced the excavated parking lot, widening the beach and the buffer zone against flooding. The relocated parking lot was finished in 2011, signaling the successful end of Phase 1 of the project [58,59]. To supplement the retreat action, the city also engaged in beach renourishment and planted sand dunes with natural vegetation with the help of local volunteers. Management of Surfers' Point is currently carrying out Phase 2, which focuses on maintaining dunes and bioswales to capture and filter storm water runoff as well as buffer the bike path against waves [60]. The Surfrider Foundation, which was involved in the managed retreat plan, actively posts online updates about the project's progress and future plans.

\subsubsection{South Ocean Beach}

In San Francisco, El Niño waves once devoured more than 40 feet of bluffs in one season at South Ocean Beach, and the area stands to lose more than 275 feet by $2100[49,61]$. Years of debates between the City of San Francisco, the CCC, and environmental and surfing groups, including the California Coastal Protection Network and the Surfrider Foundation, escalated to multiple lawsuits as stakeholders argued over best practices for managing the threats [61]. While no private property was involved, discord arose over two conflicting concerns: protection of a beach and popular surf spot, and protection of public works facilities, including the Lake Merced Tunnel and wastewater infrastructure that was built in the 1980s and 1990s in response to the Clean Water Act. Concerns for the structural integrity of the coastline had been increasing since the 1990s. Eventually, the San Francisco Planning and Urban Research Association (SPUR) stepped in to deliberate discussions between diverse stakeholders such as Golden Gate National Recreation Area, San Francisco Park \& Recreation, San Francisco Public Utilities Commission, Surfrider Foundation, and Golden Gate Audubon [62]. In 2012, these talks culminated in an innovative plan to address the complex issues of the area. The plan, which includes closing part of the Great Highway, allowing dunes to move inland, and restoring native vegetation to anchor dunes, won widespread political support [62]. The city ultimately agreed to take down a rock wall and convert two lanes of highway to a coastal trail. However, due to the need to protect essential wastewater infrastructure, the city conceded to maintain a smaller seawall (over a shorter distance) and use sand replenishment every 10 years. This combination of managed retreat and reduced hard barriers comprised the 2012 Ocean Beach Master Plan. This inter-agency effort was designed to be implemented in stages. Short-Term Improvements included sand replenishment and sand bagging with continued monitoring of these temporary protections. This phase of the project allows for protection of the beach and infrastructure while the Long-Term Improvements are made. Long-Term Improvements will include the managed retreat efforts: reshaping the bluffs, removing the necessary stretch of the Great Highway between Sloat and Highway 35, removing rubble, continuing beach renourishment, and installing a low seawall. This work will ultimately achieve both goals: improving the beach for recreation and conservation while protecting 
the Lake Merced Tunnel and the wastewater infrastructure. Since its development in 2012, the project has already moved through the Short-Term Improvements and is set to begin the Long-Term Improvements in early 2023, which are estimated to last for 4 years $[63,64]$.

\subsubsection{Marina}

The small town of Marina is in Monterey County where nearby Fort Ord, a former Army base located on the coast of Monterey Bay, was closed in 1994 in response to the 1988 Base Realignment and Closure Act. This area is known for one of the highest rates of erosion in the state, up to 5-8 feet a year [65]. Further challenges to coastal management in Marina include increased erosion due to sand removal by the Cemex company and the proposed establishment of a desalination plant in the area [65]. Additionally, with a third of the community considered low income, demographics suggest the residents of Marina may be less likely than more affluent communities to be prepared for SLR-related hazards [27-29]. Despite the socio-economic challenges, the SLR plan was met with little resistance. Indeed, stakeholders reported community pressure successfully resulted in an agreement with Cemex to phase out sand removal by the end of 2020 and to completely move out and sell the land to an entity that will ensure preservation of the property in perpetuity within three years. Residents are also fighting the desalination project and have established a plan that bans the construction of seawalls. Additionally, the plan establishes triggers for when office buildings and other public infrastructure should be relocated. Impressively, the community has secured support from a privately owned beach resort that has bought into the plan and is looking into the option of turning single-story cottages further inland into two-stories as buildings closer to the coast will need to be taken down [65].

\subsection{Emergent Themes}

We identified key differences in communication and context around managed retreat between the cases that were receptive vs. resistant to this adaptation strategy (Table 2). Building on the commonalities among the receptive cases and learning from how they contrast with the resistant cases, we provided a roadmap for future managed retreat communication efforts (Figure 2). In reviewing these two groups of cases, three prominent themes emerged: (1) importance of early and maintained communication; (2) public versus private property; and (3) stakeholder reluctance to change.

Table 2. Commonalities within cases of receptiveness and resistance toward managed retreat across emergent themes.

\begin{tabular}{llll}
\hline \multicolumn{1}{c}{ Theme } & Receptive to Managed Retreat & Resistant to Managed Retreat \\
\hline Early E maintained communication & - & $\begin{array}{l}\text { Early community education and } \\
\text { involvement with a focus on } \\
\text { community identity } \\
\text { Environmental, community residents, } \\
\text { and government groups work together } \\
\text { throughout the process }\end{array}$ & $\begin{array}{l}\text { Breakdown of communication (e.g., } \\
\text { inconsistent, exclusive, or via } \\
\text { ineffective strategy) } \\
\text { No unifying vision among } \\
\text { stakeholders }\end{array}$ \\
\hline Public vs. private property & Primarily involves public property & - & $\begin{array}{l}\text { Involves private property (esp. } \\
\text { wealthier holdings) }\end{array}$ \\
\hline Stakeholder reluctance to change & - $\begin{array}{l}\text { Emphasis on the future and on public } \\
\text { benefits, e.g., coastal access }\end{array}$ & $\begin{array}{l}\text { Focus on property rights, place } \\
\text { identity, and fear/conspiracies; } \\
\text { Lawyer involvement, ousting of } \\
\text { elected officials creates divisiveness }\end{array}$ \\
\hline
\end{tabular}


Roadmap for Communicating Managed Retreat

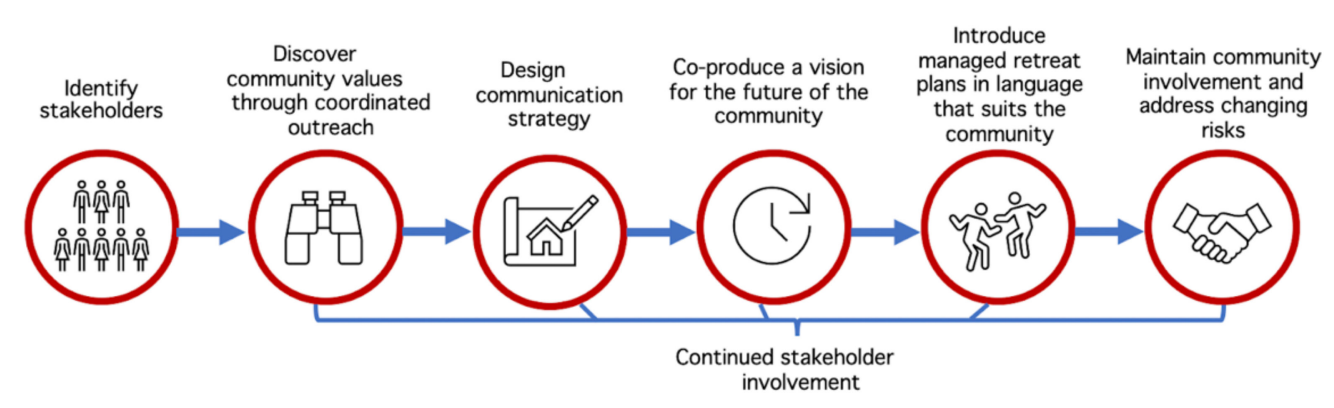

Figure 2. Roadmap for Communicating Managed Retreat.

\subsubsection{Importance of Inclusive, Early and Maintained Communication}

The process of managed retreat affects an entire community and is cross-sectoral, so communication must be inclusive of different segments of a community. For example, managed retreat framed as a real estate problem primarily engages those owning properties, setting property policy, and advocating for various property compensation choices. By contrast, managed retreat portrayed as a social problem brings in a different set of actors, including businesses, recreational interests, environmentalists, and government groups, each with different perspectives and priorities. To achieve effective communication, an overall vision that is equitable and beneficial for all stakeholders must be established and communicated to the varied stakeholders in a way that emphasizes their unique values and language [24]. One way to achieve this goal is through co-producing the vision with community stakeholders and involving them iteratively throughout the process by using scenario methods [66,67]. Additionally, when residents learn about plans from a trusted local source who supports the changes, they are more likely to be accepting [11]. As more people support the plan, the effect snowballs, as residents who are initially against managed retreat may concede to the idea when it becomes evident that others in the community are planning to relocate [21]. Developing inclusive communication about managed retreat is an important way to achieve sustainable development and reduce climate disaster risks for vulnerable communities and countries.

Early identification of community values can be achieved through workshops, community meetings, intercept interviews, and meetings with homeowners to provide personalized information about risk [68]. Marina Mayor Bruce Delgado stressed that Marina has a long history of community concern for protecting their beaches and has successfully fought to stop the sand mining activities that damage their beach. This community focus on a common goal was noted as an asset in adaptive planning. However, strong community values can also hinder managed retreat efforts. For example, in King Salmon, where residents value their affordable ocean access, city officials must find ways to maintain residents' access to the ocean while presenting managed retreat as a safer and less costly option for the long-term. Furthermore, studies have shown that the economic status and age of the residents will affect their perspectives of managed retreat $[69,70]$, indicating the importance of accounting for these factors when crafting the plan for community engagement.

The cases where managed retreat lacked community support often showed a deterioration of communication among coastal stakeholders, consultants, and elected officials that eventually led to complete abandonment of the review process. One key factor to successful planning is having an effective moderator who can bring together various stakeholders and explain management options. Avoiding jargon whenever possible is important because many terms will be viewed differently by different stakeholders [71]. According to David Revell, a consultant, who works on managed retreat cases in California, even the term "triggers" can be triggering for coastal stakeholders. Revell explained that he would never 
use the term "managed retreat" without explaining examples of the process, thus avoiding false assumptions and interpretations of what is being discussed. For example, Del Mar, a city which loudly opposed the idea of managed retreat, states that part of their adaptation plan includes monitoring flooding events to determine whether the frequency of flooding and storm damage "is becoming unsustainable to rebuild in the same location" [41]. Early and active education about the varied aspects of managed retreat could help garner support for these actions. It is important to convey that the "managed" part of managed retreat allows towns to have a calm, coordinated, structured plan with environmental triggers indicating when steps need to be taken.

\subsubsection{Public vs. Private Property}

Private property complicates management negotiations for at least four reasons: 1 . personal financial loss means impacts are concentrated on homeowners rather than being shared more widely by a community, 2 . emotional ties to properties are intensified by private ownership, 3. relinquishing home ownership prevents passing owned properties to one's descendants, and 4. multiple property owners increase the number of highly invested stakeholders who want to have a voice in decisions, making negotiations more complex and time-consuming.

Most of the successful cases of managed retreat identified here involve public land, and perhaps more importantly, public funding. In general, managed retreat may be funded by taxpayers including those in the affected communities, the public sector including local or state government and public insurers, or the private sector including private insurers [72]. In the past, Californians have voted for tax increases that fund voluntary buyouts and relocation of property in flood-prone areas [73]. Shifting the funding burden of managed retreat from private to public funding and focusing efforts on shared community spaces may help increase community support and ease the incorporation of managed retreat projects into local planning.

Areas that involved private property, particularly wealthier holdings like Del Mar, were more reluctant to accept managed retreat as a possible future. For some homeowners, especially those wishing to pass their home on to their children, buy-outs may seem the only feasible option. However, when the government buys back houses at their prehazard prices it has a distorting effect on the market and can incentivize increased risk exposure by offering coastal homeowners a guaranteed safety net [74]. There is not a one size fits all solution for private property owners but the Federal Government may take action to prevent this issue by terminating flood insurance for properties with repeated claims or raising federal flood insurance premiums to reflect the actual costs of coastal flooding $[75,76]$. Additionally, stakeholders who may be reluctant to managed retreat because of the high economic value of their coastal property should be made aware that property values decline with frequent flooding, and of the large, collective losses that occur with unmanaged retreat $[77,78]$.

The issue of private property can create local division on the issue of managed retreat. A local government official in Pacifica identified possible mechanisms of division, including: property owners vs. recreational users, home-owners with property near to vs. far from the coast, and economic status (with wealthy property owners against managed retreat). Length of residency in the town, however, was not associated with opposition to retreat; indeed, the official noted that many long-time Pacifica residents supported including retreat in the LCP.

In South Ocean Beach and Marina, efforts for managed retreat were likely facilitated by the fact that no or limited private property was involved in the plan. In South Ocean Beach, a successful agreement was reached when a mediator, the San Francisco Planning and Urban Research Association, was able to bring together numerous stakeholders with a long history of arguments and lawsuits. While agreement was not easy, the lack of private property interests likely facilitated and expedited planning negotiations. Managed retreat in Marina also primarily involved public lands, making it an ideal location for gaining public 
receptiveness toward managed retreat. Furthermore, impacted infrastructure is largely owned by state parks, and the sole private business owner who faces the most immediate personal impacts supports managed retreat. However, even with these seemingly ideal conditions, consultants and local governmental officials took care to deliberately present plans as gradual, forward-looking, and focused on community identity and priorities.

\subsubsection{Stakeholder Reluctance to Change}

One of the biggest challenges to implementing managed retreat is gaining support from a community that recognizes the dangers of rising sea levels but would rather tolerate flooding and stay in their current place-even for a limited time-rather than move to a safer location for the long term. Place attachment, a cognitive association with a physical space or environment, is prominent in communities with strong social capital where members trust the efficacy of group action and are empowered by a sense of belonging $[79,80]$. In communities that were supportive of managed retreat as a method for protecting local ecosystem services such as beach/surf access, such as Marina and Surfer's Point, this place attachment can be easily used as a tool for managers in gaining support for managed retreat. However, when the homes of these individuals are threatened, this same place attachment can hinder managed retreat efforts. Community cohesion can be leveraged by incorporating residents early in the management planning process and gaining support from community leaders who will champion the idea of managed retreat.

Managed retreat efforts that were unsuccessful were marked by a focus on property rights, fear of change, climate change conspiracies, and the involvement of lawyers before plans for managed retreat were abandoned or severely altered. Sometimes, under extreme pressure, elected officials were even ousted. These obstacles are reactionary and may arise from stakeholders' misunderstanding of the SLR timeline and/or managed retreat process. To combat this reaction, early outreach on the incremental nature of managed retreat is essential. Additionally, stakeholders must be informed early on that their participation is and always will be voluntary, fair, and in their best interest.

To elicit community support, city officials should assess the attitudes of residents with surveys or workshops to understand the predominant worldviews, priorities, and values. A managed retreat plan can then be designed with these priorities in mind and communication can be tailored to emphasize how the plan supports and protects the community's values. For example, the community at Surfers' Point had a strong emotional connection to the natural surf break, and because community members were involved in the planning process from the beginning, they were able to prioritize preserving beach access in their management plan. Relocating will preserve beach habitat and increase coastal access, which are common values among many coastal communities. Where possible, it may be helpful to begin a management plan with a focus on relocating public infrastructure, such as roads and parking lots, before adding areas with private property as high-risk. Finally, city councils should be proactive; even if managed retreat is not necessary at the present time, the adaptation plan should clearly outline the thresholds at which managed retreat would become the best option so that communities are prepared for this future scenario.

\section{Discussion}

Managed retreat contributes to sustainable development as it considers global solutions for social vulnerability and climate change mitigation, sustainable economic development, and corporate and non-corporate social responsibilities. While this study focuses on California, there is potential for this study's findings to be useful in coastal regions throughout the world such as Mediterranean countries that share California's climate and flood risk. Coastal planning is not a simplistic process; many aspects complicate effective progress including permitting and legal processes, geology, funding sources, insurance programs, distribution of financial risks, and the occurrence of episodic severe erosion events (e.g., El Niño years). Throughout California, efforts to achieve community support for managed retreat have had mixed results, despite being the only viable option in cases 
where geomorphology does not support defensive measures. One salient aspect that we identified in the receptive cases examined here was the importance of effective communication of managed retreat. Past instances of miscommunication have led to a tendency to associate managed retreat with negative feelings of failure and surrender. Here, we introduce a roadmap for communicating managed retreat and provide suggestions for rebranding the term itself.

\subsection{Roadmap for Communicating Managed Retreat}

In reviewing cases of receptiveness and resistance toward managed retreat, we identified three themes to consider when crafting an effective communication plan: (1) early and maintained communication; (2) public versus private property concerns; and (3) stakeholder reluctance to change. In order to more effectively communicate the actions currently termed managed retreat, we proposed a roadmap based on these three themes (Figure 2).

Step 1: Identify stakeholders: It is imperative that the process of coastal planning begins early by identifying and engaging stakeholders. These include property and business owners who will be immediately impacted by planning decisions, local governments, advocacy groups, and the broader community.

Step 2: Discover community values through coordinated outreach: Stakeholder values should be ascertained through a coordinated outreach effort focused on community identity. This effort can include public forums, door-to-door engagement, mailings, and news alerts, among other communication methods. This period of exploration and discussion is key to ensuring that planners recognize the unique community concerns, goals, and needs.

Step 3: Design communication strategy: Using information about the community's values and the varied stakeholders, a communication strategy can be developed. Haphazard, uncoordinated, inconsistent, and unstructured communication can be a source of misunderstanding, fear, and anxiety, which can lead to a breakdown of the planning process. Therefore, care must be taken to develop an effective and coordinated communication process which may require skilled consultants, coastal planners, mediators, or cooperative groups who have experience dealing with diverse interest groups and navigating contentious issues.

Step 4: Co-produce a vision for the future of the community: The coordinated communication plan developed in Step 3 should be employed to engage stakeholders in a collaborative effort to identify a common vision for the future of the community. Professional and experienced consultants, coastal planners, mediators, and cooperative groups will be important resources in this step to help keep discussions focused and productive while ensuring an effective communication process where all groups feel heard and valued.

Step 5: Introduce managed retreat plans in language that suits the community: Each community will have unique needs and specifics that require a tailored communication program that is centered on the future vision for that community. With stakeholders as key players in identifying values, developing the vision, and informing communication, a customized introduction of managed retreat can begin. We further recommend rebranding the term "managed retreat", discussed in more detail below, to help avoid pitfalls of historical associations with a term that triggers contention.

Step 6: Maintain community involvement and address changing risks: Coastal planning is an ongoing process. As the environment continues to change, so must adaptation plans. Consistent, sustained community involvement will strengthen a sense of investment and aid in making modifications that take changing conditions into account. For instance, adaptation plans that involve managed retreat could begin by introducing regulatory techniques such as setbacks (identifying high-risk areas where new developments would be prohibited), and then expanding to existing developments, as well as implementing buy-out programs when feasible.

Our roadmap encourages the focus of coastal planning to remain on each community's unique needs and circumstances while continuously engaging the community and key players in the process. Professional consultants, coastal planners, mediators, and 
cooperative groups are important resources throughout the process to ensure consistent communication. A central goal throughout the communication process should be to emphasize managed retreat as a sustainable development strategy that (1) protects communities by moving out of a hazard zone, rather than a strategy of surrender, (2) expands public access to ecosystem services, (3) preserves natural resources, and (4) balances long-term costs and benefits associated with repeated rebuilding after catastrophic events such as El Niños and progressive changes such as sea-level rise.

\subsection{Rebranding Managed Retreat}

An important aspect of this roadmap is a shift in terminology that is necessitated by the unfortunate history of the term "managed retreat." Both past miscommunications and the application of the terms "managed" and "retreat" in other contexts has led to a situation where "managed retreat" can evoke negative public responses. "Retreat" can conjure "failure" or "defeat," particularly in areas with military histories [49,52,81]. However, the term's etymology reveals a more positive interpretation: combining re- "go back" and treat- "to heal or cure," retreat can be seen as a process of returning in order to repair [9]. Additionally, "managed" is meant to indicate a situation brought under control or to "succeed in accomplishing" [82], yet it can also elicit a sense of losing one's independence to outsider influence. This can be particularly true in Native American communities that have a long history of government distrust [83]. According to the famed linguist George Lakoff, every word evokes a frame with which people have a cognitive association [84]. Frames are strategic tools of social movements because of their power to mobilize various actors $[85,86]$. Effective policy uses frames that tie specific wording to fundamental values and avoids terms that conjure alternative ideas. Since managed retreat is negatively associated with loss of property, some reframing of the term is needed to bring back its original etymological meaning.

Currently, negative perceptions around managed retreat are so pervasive that people immediately reject language associated with the actions that would take place under this process, even when the words "managed retreat" are never used. For example, the Del Mar community strongly opposed long-term future planning and identifying triggers for large-scale action. Re-branding could make the themes behind "managed retreat" more appealing to communities, shifting the focus from abandonment and surrender to proactively securing a community's future. Notably, officials should be specific with their language. Examples of retreat following a catastrophe, as in the case of Hurricane Sandy in New York, are often pushed under the umbrella of managed retreat. However, unplanned abandonment is not a management plan; rather, it is an emergency response. It should be emphasized that the precise purpose of a managed retreat plan is to avoid just such emergency responses by identifying the probability of such catastrophes and preventing devastating outcomes.

We recommend the following phrasing to inspire and evoke the frames associated with the original intention of the managed retreat; that is, to "go back" in order "to heal or cure." Further research is needed to investigate how stakeholders respond to new terminology and framing, perhaps through focus groups and social marketing techniques [87-89]:

- $\quad$ Planned and managed realignment;

- Corrective shoreline planning;

- Hazard avoidance;

- Managed realignment;

- Managed relocation;

- Community-led relocation;

- Graceful withdrawal.

\section{Conclusions}

Coastal adaptation is an increasingly important and complex process where multiple, often conflicting, interests and processes must come together to reach effective and sus- 
tainable development goals and outcomes. While many processes—such as permitting and legal processes, geology, funding sources, and distribution of financial risks-will take further action, improving communication strategies is within immediate reach and has the potential to have significant impacts on the outcomes of adaptation planning. Here, we identify key factors common to receptive communities and use these factors to structure a rebranding of the communication of the process currently termed managed retreat. We recommend: (1) a roadmap for communicating managed retreat which emphasizes the need to identify and engage stakeholders; focus on community values and a future vision; employ professional consultants, coastal planners, mediators, and cooperative groups; and maintain continued and engaged communication with an eye to adjusting to changing risks; and (2) rebranding the term "managed retreat" to move away from a triggering term and toward one that evokes a proactive, coordinated, and calm movement out of harm's way. We suggest some possible new terms and encourage future research, through focus groups and social marketing techniques, to identify the most effective terminology to implement moving forward.

Author Contributions: Conceptualization, A.D.S., W.K.B., S.T.G., and A.R.; methodology, W.K.B., S.T.G., A.R., and A.D.S.; formal analysis, W.K.B., S.T.G., A.R., and A.D.S.; investigation, W.K.B., S.T.G., and A.D.S.; writing — original draft preparation, S.T.G., W.K.B., A.D.S., and A.R.; writingreview and editing, W.K.B., S.T.G., A.R., and A.D.S.; visualization, A.D.S., W.K.B., and S.T.G.; project administration, W.K.B., S.T.G., A.R., and A.D.S. All authors contributed to the creation of this manuscript. All authors have read and agreed to the published version of the manuscript.

Funding: The authors were supported by many funding sources for graduate study while conducting this research: W.K.B. was supported by UCSC Women's Club and Marilyn C. Davis Foundation Re-entry Scholarships and UCSC EEB Department; S.T.G. was supported by a Ford Foundation Predoctoral Fellowship and UCSC EEB Department; A.D.S. was supported by a UCSC Regents Fellowship. A.R received fellowship support from the UCSC Coastal Science and Policy program, a scholarship from the Wildlife Conservation Society and a scholarship from the Wildlife Conservation Network.

Institutional Review Board Statement: The study was conducted according to the guidelines of the Declaration of Helsinki and approved by the Institutional Review Board (or Ethics Committee) of UC Santa Cruz (protocol code 3764 approved on 10/13/2020).

Informed Consent Statement: Informed consent was obtained from all subjects involved in the study.

Data Availability Statement: Not Applicable.

Acknowledgments: The authors thank Anne Kapuscinksi, Borja Gonzalez-Reguero, and Tiffany Wise-West for their mentorship and revisions that greatly improved the quality of this manuscript. We thank Resilient Coast Santa Cruz for providing several Climate Adaptation Planning Support documents. We also thank the students of the UCSC Coastal Science and Policy course on Adaptation and Planning for the discussions and feedback on our initial draft of this paper.

Conflicts of Interest: The authors declare no conflict of interest.

\section{References}

1. Griggs, G.; Árvai, J.; Cayan, D.; DeConto, R.; Fox, J.; Cayan, D.; Fricker, H.; Kopp, R.; Tebaldi, C.; Whiteman, E. California Ocean Protection Council Science Advisory Team Working Group. Rising Seas in California: An Update on Sea-Level Rise Science. Calif. Ocean Sci. Trust. 2017. Available online: https://www.oceansciencetrust.org/wp-content/uploads/2017/04/OST-Sea-LevelRising-Report-Final_Amended.pdf (accessed on 1 December 2020).

2. Barnard, P.L.; Erikson, L.H.; Foxgrover, A.C.; Hart, J.A.F.; Limber, P.; O’Neill, A.C.; van Ormondt, M.; Vitousek, S.; Wood, N.; Hayden, M.K.; et al. Dynamic Flood Modeling Essential to Assess the Coastal Impacts of Climate Change. Sci. Rep. 2019, 9, 1-13. [CrossRef]

3. Kythreotis, A.P.; Mantyka-Pringle, C.; Mercer, T.G.; Whitmarsh, L.E.; Corner, A.; Paavola, J.; Chambers, C.; Miller, B.A.; Castree, N. Citizen Social Science for More Integrative and Effective Climate Action: A Science-Policy Perspective. Front. Environ. Sci. 2019, 7, 10. [CrossRef] 
4. Russell, N.; Griggs, G. Adapting to Sea Level Rise: A Guide for California's Coastal Communities; University of California: Santa Cruz, CA, USA, 2012; p. 56.

5. [CCCSLR], California Coastal Commission Sea Level Rise Adaptation Strategies. SLR_Vulnerability \& Adaptation. Available online: https: / / www.coastal.ca.gov / climate/slr/vulnerability-adaptation/adaptation/ (accessed on 29 December 2020).

6. Nicholls, R.J. Planning for the Impacts of Sea Level Rise. Oceanography 2011, 24, 144-157. [CrossRef]

7. Neal, W.J.; Bush, D.M.; Pilkey, O.H. Managed Retreat. In Encyclopedia of Engineering Geology; Finki, C., Makowski, C., Eds.; Encyclopedia of Earth Sciences Series; Springer International Publishing: Cham, Switzerland, 2017; pp. 1-7. ISBN 978-3-31912127-7.

8. California Coastal Commission. California Coastal Commission Residential Adaptation Policy Guidance. Interpretive Guidelines for Addressing Sea Level Rise in Local Coastal Programs; California Coastal Commission: San Francisco, CA, USA, 2018 ; p. 95.

9. Koslov, L. The Case for Retreat. Public Cult. 2016, 28, 359-387. [CrossRef]

10. Alexander, K.S.; Ryan, A.; Measham, T.G. Managed Retreat of Coastal Communities: Understanding Responses to Projected Sea Level Rise. J. Environ. Plan. Manag. 2012, 55, 409-433. [CrossRef]

11. Kochnower, D.; Reddy, S.M.W.; Flick, R.E. Factors Influencing Local Decisions to Use Habitats to Protect Coastal Communities from Hazards. Ocean Coast. Manag. 2015, 116, 277-290. [CrossRef]

12. Abel, N.; Gorddard, R.; Harman, B.; Leitch, A.; Langridge, J.; Ryan, A.; Heyenga, S. Sea Level Rise, Coastal Development and Planned Retreat: Analytical Framework, Governance Principles and an Australian Case Study. Environ. Sci. Policy 2011, 14, 279-288. [CrossRef]

13. Abbott, T. Shifting Shorelines and Political Winds-The Complexities of Implementing the Simple Idea of Shoreline Setbacks for Oceanfront Developments in Maui, Hawaii. Ocean Coast. Manag. 2013, 73, 13-21. [CrossRef]

14. NC DEQ: Oceanfront Construction Setback \& Erosion Rates. Available online: https://deq.nc.gov/about/divisions/coastalmanagement/coastal-management-oceanfront-shorelines/oceanfront-construction-setback-erosion-rate (accessed on 21 December 2020).

15. Ganguli, P.; Merz, B. Trends in Compound Flooding in Northwestern Europe During 1901-2014. Geophys. Res. Lett. 2019, 46, 10810-10820. [CrossRef]

16. Kastridis, A.; Stathis, D. Evaluation of Hydrological and Hydraulic Models Applied in Typical Mediterranean Ungauged Watersheds Using Post-Flash-Flood Measurements. Hydrology 2020, 7, 12. [CrossRef]

17. Faccini, F.; Luino, F.; Paliaga, G.; Sacchini, A.; Turconi, L.; de Jong, C. Role of Rainfall Intensity and Urban Sprawl in the 2014 Flash Flood in Genoa City, Bisagno Catchment (Liguria, Italy). Appl. Geogr. 2018, 98, 224-241. [CrossRef]

18. California Coastal Management Program. In State of California Sea-Level Rise Guidance. Available online: http:/ / www.opc.ca.gov/ webmaster/ftp/pdf/agenda_items/20180314/Item3_Exhibit-A_OPC_SLR_Guidance-rd3.pdf (accessed on 29 November 2020).

19. Resources Agency of California. Resources Agency of California Draft Policy on Coastal Erosion Planning and Response; The Resources Agency: Sacramento, CA, USA, 2001.

20. O'Donnell, T. Legal Geography and Coastal Climate Change Adaptation: The Vaughan Litigation. Geogr. Res. 2016, 54, 301-312. [CrossRef]

21. Hino, M.; Field, C.; Mach, K. Managed Retreat as a Response to Natural Hazard Risk. Nature Climate Change. Nat. Clim. Change 2017, 7, 364-370. [CrossRef]

22. Moser, S.C. Communication Strategies to Mobilize the Climate Movement. In Ignition: What You Can Do to Fight Global Warming and Spark a Movement; Isham, J., Waage, S., Eds.; Island Press: Washington, DC, USA, 2007.

23. Loeb, P.R. Introduction to Part Four. In The Impossible Will Take a Little While: A Citizen's Guide to Hope in a Time of Fear; Basic Books: New York, NY, USA, 2004.

24. Moser, S.C.; Dilling, L. (Eds.) Creating a Climate for Change: Communicating Climate Change and Facilitating Social Change; Cambridge University Press: Cambridge, UK, 2007.

25. Anderson, J.; Laird, A.; Patton, J. Comments on the 2017 Rising Seas in California: An Update on Sea-Level Rise Science and the Upcoming Update to California's Sea-Level Rise Guidance Document; Local Reports and Publications, Humboldt State University Sea Level Rise Initiative; Humboldt State University: Arcata, CA, USA, 2017.

26. U.S. Census Bureau. 2017 American Community Survey 5 Year Estimates-Table B19001. Available online: https:/ / data.census. gov (accessed on 12 May 2020).

27. Collins, T.W.; Grineski, S.E.; Chakraborty, J.; Flores, A.B. Environmental Injustice and Hurricane Harvey: A Household-Level Study of Socially Disparate Flood Exposures in Greater Houston, Texas, USA. Environ. Res. 2019, 179, 108772. [CrossRef]

28. Qiang, Y. Disparities of Population Exposed to Flood Hazards in the United States. J. Environ. Manag. 2019, 232, 295-304. [CrossRef]

29. Winsemius, H.C.; Jongman, B.; Veldkamp, T.I.E.; Hallegatte, S.; Bangalore, M.; Ward, P.J. Disaster Risk, Climate Change, and Poverty: Assessing the Global Exposure of Poor People to Floods and Droughts. Environ. Dev. Econ. 2018, 23, 328-348. [CrossRef]

30. Kunkel, K. Exploring Community Knowledge and Perceptions of Flooding and Sea-Level Rise in King Salmon, California. Master's Thesis, Humboldt State University, Arcata, CA, USA, 2019. 
31. Laird, A. Communities at Risk, Sea Level Rise Vulnerability Assessment. Humboldt Cty. Humboldt Bay Area Plan 2019. Available online: https://humboldtgov.org/DocumentCenter/View/81418/Humboldt-Bay-Area-Plan-Communitiesat-Risk-SLR-Vulnerability-Assessment-12-02-2019-?bidId=https:/ / humboldtgov.org/DocumentCenter/View / 81418 / Humboldt-Bay-Area-Plan-Communities-at-Risk-SLR-Vulnerability-Assessment-12-02-2019-?bidId=; https://humboldtgov. org/DocumentCenter/View/65367/King-Salmon-and-Fields-Landing--8-7-2018-Workshop-Notes-PDF (accessed on 12 May 2020).

32. Robinson, C.; Davidson, R.; Trainor, J.; Kruse, J.; Nozick, L. Homeowner Acceptance of Voluntary Property Acquisition Offers. Int. J. Disast. Risk Reduct. 2018, 31, 234-242. [CrossRef]

33. Bukvic, A.; Zhu, H.; Lavoie, R.; Becker, A. The Role of Proximity to Waterfront in Residents' Relocation Decision-Making Post-Hurricane Sandy. Ocean Coast. Manag. 2018, 154, 8-19. [CrossRef]

34. Binder, S.B.; Baker, C.K.; Barile, J.P. Rebuild or Relocate? Resilience and Postdisaster Decision-Making After Hurricane Sandy. Am. J. Community Psychol. 2015, 56, 180-196. [CrossRef]

35. Vries, D.; Fraser, J. Citizenship Rights and Voluntary Decision Making in Post-Disaster U.S. Floodplain Buyout Mitigation Programs. Int. J. Mass Emerg. Disasters 2012, 30, 1-33.

36. Diehl, P. New Federal Map Shows Increased Danger of Flooding in Del Mar. Del Mar Times, 14 July 2019.

37. [STAC] Sea-Level Rise Stakeholder-Technical Advisory Committee Agenda. Available online: http://www.delmar.ca.us/ AgendaCenter/ViewFile/Agenda/1835?html=true (accessed on 12 May 2020).

38. City of Del Mar LCP Amendment. Staff Recommendation on City of Del Mar Major Amendment LCP-6-DMR18-0082-1 (Sea Level Rise) for Commission Meeting of 16-18 October 2019. Available online: https:/ / documents.coastal.ca.gov/reports/2019/10/W10a/W10a8-2019-report.pdf (accessed on 20 July 2020).

39. Mulkern, A.C. Coastal City Refuses to Retreat-Scientific American. Available online: https://www.scientificamerican.com/ article/coastal-city-refuses-to-retreat/ (accessed on 21 December 2020).

40. [CDM] City of Del Mar Website Sea-Level Rise Local Coastal Program Amendment I Del Mar, CA-Official Website. Available online: http:/ / www.delmar.ca.us / 498/Sea-Level-Rise-Local-Coastal-Program-Ame (accessed on 29 December 2020).

41. Diehl, P. Del Mar Will Stand Its Ground against Managed Retreat. San Diego Union-Tribune, 8 October 2019.

42. Harold, L. Del Mar Looks to Postpone Coastal Commission Hearing over Sea Level Rise to July. Del Mar Times, 15 January 2020.

43. Del Mar City Council Meeting Revised Agenda 2020. Available online: http://www.delmar.ca.us / AgendaCenter (accessed on 20 December 2020).

44. Kershner, J. Restoration and Managed Retreat of Pacifica State Beach I CAKE: Climate Adaptation Knowledge Exchange. Available online: https:/ / www.cakex.org/case-studies/restoration-and-managed-retreat-pacifica-state-beach (accessed on 21 December 2020).

45. Preliminary Draft Adaptation Plan, Pacifica, CA; 2018. Available online: https://www.cityofpacifica.org/civicax/filebank/ blobdload.aspx?BlobID=14285 (accessed on 20 December 2020).

46. Consideration of Local Coastal Program (LCP) Consultation Draft-City of Pacifica, California. Available online: https: / / pacificacityca.iqm2.com/Citizens /Detail_LegiFile.aspx?Frame=\&MeetingID=1312\&MediaPosition=\&ID=3071\&CssClass= (accessed on 6 February 2021).

47. Jarosz, B. Sea Level Rise Preparation Plan Puts Pacifica Property Owners on Edge. KTVU Fox 2 News, 29 November 2018.

48. Xia, R. California against the Sea; Hotter Planet Leaves Only Tough Choices. Los Angeles Times, 7 July 2019.

49. Dyett \& Bhatia Urban and Regional Planners City of Pacifica Local Coastal Land Use Plan. 2020. Available online: https: / / www.cityofpacifica.org/ civicax/filebank/blobdload.aspx?blobid=4438 (accessed on 26 December 2020).

50. City of Imperial Beach Sea Level Rise Assessment 2016. Available online: https://www.imperialbeachca.gov/sea_level_rise (accessed on 26 December 2020).

51. Cart, J. Back off the Beach and the Rising Sea? No Way, California Cities Say. Available online: https://calmatters.org/ environment/2020/04/california-coast-rising-seas-climate-change/ (accessed on 29 December 2020).

52. General Plan/Local Coastal Program (LCP) Update and Climate Action Plan (CAP) for the 2019 Resilient Imperial Beach (RIB) Project; Community Development: Imperial City Beach, CA, USA, 2019.

53. Revised Final Draft City of Imperial Beach General Plan/Local Coastal Program Land Use Plan; Community Development: Imperial City Beach, CA, USA, 2019.

54. Patsch, K.; Griggs, G. Littoral Cells, Sand Budgets, and Beaches: Understanding California's Shoreline; Institute of Marine Sciences, University of California: Santa Cruz, CA, USA, 2006.

55. Jenkin, P. Managed Shoreline Retreat and Dam Removal: Ecosystem Restoration to Benefit Coastal Resources. Reef J. 2009, 1, 140-152.

56. U.S. Climate Resilience Toolkit. Restoring Surfers' Point. Available online: https://www.climate.gov/news-features / climatecase-studies / restoring-surfers-point (accessed on 12 May 2020).

57. Jenkin Surfers' Point-Phase 1 Complete. Available online: https://www.venturariver.org/2011/07/surfers-point-phase-1complete.html (accessed on 12 May 2020). 
58. [SPMSR] Surfers' Point Managed Shoreline Retreat. Available online: http://matilija-coalition.org/point/ (accessed on 12 May 2020).

59. Jenkin Surfers' Point Phase 2 Update. Available online: https://www.venturariver.org/search/label/Surfers\%20Point (accessed on 20 December 2020).

60. Barboza, Tony Environmentalists Hope to Turn the Tide Against Use of Sea Walls. Available online: https://www.latimes.com/ local/la-xpm-2012-jan-02-la-me-san-francisco-strand-20120102-story.html (accessed on 29 December 2020).

61. Managed Retreat. In San Francisco Estuary Partnership; San Francsico, CA, USA. 2013. Available online: https:/ /www.sfestuary. org/estuary-news/managed-retreat/ (accessed on 21 December 2020).

62. [SFPOBA] San Francisco Planning Ocean Beach Adaptation. Available online: https://sfplanning.org/ocean-beach (accessed on 12 May 2020).

63. [SFPUC] San Francisco Public Utilities Commission. Ocean Beach Climate Change Adaptation Project. Available online: https: / / sfwater.org / index.aspx?page=1216 (accessed on 12 May 2020).

64. Xia, R. Seeing the Threat, Coastal Town Rises to the Challenge; as Other Cities Dig in, Marina Embraces a Policy of Managed Retreat. Los Angeles Times, 24 February 2020. Available online: enewspaper.latimes.com/infinity/article-share.aspx?guid=47944c1 a-36b7-4474-9b3e-77b6ed9ce366(accessed on 26 December 2020).

65. Enfors, E.I.; Gordon, L.J.; Peterson, G.D.; Bossio, D. Making Investments in Dryland Development Work: Participatory Scenario Planning in the Makanya Catchment, Tanzania. Ecol. Soc. 2008, 13, 42. [CrossRef]

66. Wollenberg, E.; Edmunds, D.; Buck, L. Using Scenarios to Make Decisions about the Future: Anticipatory Learning for the Adaptive Co-Management of Community Forests. Landsc. Urban Plan. 2000, 47, 65-77. [CrossRef]

67. Vandenbeld, A.; Macdonald, J. Fostering community acceptance of managed retreat in New Zealand. In Climate Adaptation Futures; Wiley-Blackwell: West Sussex, UK, 2013; pp. 161-166.

68. Stoltz, A.D. Determining Resilience in Cedar Key, Fort Myers Beach, and Conch Key: Fishing Industry Views on Sea Level Rise Risk and Adaptation. Available online: https:/ / scholarship.miami.edu/discovery / fulldisplay/alma991031447094102976/01 UOML_INST:ResearchRepository (accessed on 2 January 2021).

69. Siders, A.R. Managed Retreat in the United States. One Earth 2019, 1, 216-225. [CrossRef]

70. Scheer, D.; Benighaus, C.; Benighaus, L.; Renn, O.; Gold, S.; Röder, B.; Böl, G.-F. The Distinction Between Risk and Hazard: Understanding and Use in Stakeholder Communication: Distinction Between Risk and Hazard. Risk Anal. 2014, 34, $1270-1285$. [CrossRef] [PubMed]

71. Noy, I. Paying a Price of Climate Change: Who Pays for Managed Retreats? Curr. Clim. Change Rep. 2020, 6, 17-23. [CrossRef]

72. Conrad, D.; McNitt, B.; Stout, M. Higher Ground: A Report on Voluntary Property Buyouts in the Nation's Floodplains. A Common Ground Solution Serving People at Risk, Taxpayers and the Environment; National Wildlife Federation: Vienna, VA, USA, 1998.

73. Young, A.W. How to Retreat: The Necessary Transition from Buyouts to Leasing. Coast. Manag. 2018, 46, 527-535. [CrossRef]

74. Lester, C.; Matella, M. Managing the Coastal Squeeze: Resilience Planning for Shoreline Residential Development. Stanf. Environ. Law J. 2016, 36, 23-61.

75. Griggs, G.; Patsch, K. California's Coastal Development: Sea-Level Rise and Extreme Events—Where Do We Go from Here? Shore Beach 2019, 15-28. [CrossRef]

76. Dahl, K.; Cleetus, R.; Spanger-Siegfried, E.; Udvardy, S.; Caldas, A.; Worth, P. Underwater: Rising Seas, Chronic Floods, and the Implications for US Coastal Real Estate; Union of Concerned Scientists: Cambridge, MA, USA, 2018.

77. Union of Concerned Scientists. Underwater: Rising Seas, Chronic Floods, and the Implications for U.S. Coastal Real Estate. 2018. Available online: https://www.ucsusa.org/resources/underwater (accessed on 20 December 2020).

78. Proshansky, H.M.; Fabian, A.K.; Kaminoff, R. Place-Identity: Physical World Socialization of the Self. J. Environ. Psychol. 1983, 3, 27. [CrossRef]

79. Perkins, D.D.; Long, D.A. Neighborhood Sense of Community and Social Capital. In Psychological Sense of Community; Fisher, A.T., Sonn, C.C., Bishop, B.J., Eds.; The Plenum Series in Social/Clinical Psychology; Springer US: Boston, MA, USA, 2002; pp. 291-318. ISBN 978-1-4613-5209-9.

80. [CCMDM] City Council Meeting Del Mar, California Information Received After the Council Agenda Was Distributed. Available online: https://www.delmar.ca.us/AgendaCenter/ViewFile/ArchivedAgenda/_04162018-1349 (accessed on 29 December 2020).

81. Manage. Online Etymology Dictionary, 2001-2020. 2020. Available online: etymonline.com/word/manage (accessed on 27 December 2020).

82. Bacon, J.M.; Norton, M. Colonial America Today: U.S. Empire and the Political Status of Native American Nations. Comp. Stud. Soc. Hist. 2019, 61, 301-331. [CrossRef]

83. Lakoff, G. Simple Framing; Rockridge Institute Writings: Berkeley, CA, USA, 2006.

84. Goffman, E. Frame Analysis: An Essay on the Organization of Experience; Harper \& Row: New York, NY, USA, 1974.

85. Lakoff, G. Don't Think of an Elephant! Know Your Values and Frame the Debate; Chelsea Green Publishing: White River Junction, VT, USA, 2004.

86. Cameron, J. Focussing on the Focus Group. Qual. Res. Methods Hum. Geogr. 2005, 2, 116-132. 
87. Krueger, R.A.; Casey, M.A. Focus Groups. A Practical Guide for Applied Research, 5th ed.; Sage Publications, Inc.: Thousand Oaks, CA, USA, 2015.

88. Krueger, R. Designing and Conducting Focus Group Interviews. Eastern Illinois Higher Education Center. 2002. Available online: https://www.eiu.edu/ihec/Krueger-FocusGroupInterviews.pdf (accessed on 28 December 2020).

89. McKenzie-Mohr, D. Fostering Sustainable Behavior. An Introduction to Community-Based Social Marketing, 3rd ed.; New Society Publishers: Gabriola, BC, Canada, 2011. 